\title{
Chemical Identification
}

National Cancer Institute

\section{Source}

National Cancer Institute. Chemical Identification. NCI Thesaurus. Code C158435.

The identification of a chemical based on certain criteria and tests. 